\title{
Proximity to multiple foraging habitats enhances seabirds' resilience to local food shortages
}

\author{
Rosana Paredes ${ }^{1, *}$, Ann M. A. Harding ${ }^{2}$, David B. Irons ${ }^{3}$, Daniel D. Roby ${ }^{1}$, \\ Robert M. Suryan ${ }^{4}$, Rachael A. Orben ${ }^{5}$, Heather Renner ${ }^{6}$, Rebecca Young ${ }^{7}$, \\ Alexander Kitaysky ${ }^{7}$
}

\author{
${ }^{1}$ Department of Fisheries and Wildlife, 104 Nash Hall, Oregon State University, Corvallis, Oregon 97331-3803, USA \\ ${ }^{2}$ Alaska Pacific University, Environmental Science Department, 4101 University Drive, Anchorage, Alaska 99508, USA \\ ${ }^{3}$ U.S. Fish and Wildlife Service, Anchorage, Alaska 99503, USA \\ ${ }^{4}$ Oregon State University, Hatfield Marine Science Center, Newport, Oregon 97365, USA \\ ${ }^{5}$ Ocean Sciences Department, University of California Santa Cruz, Long Marine Lab, Santa Cruz, California 95060, USA \\ ${ }^{6}$ Alaska Maritime National Wildlife Refuge, U.S. Fish and Wildlife Service, Homer, Alaska 99603, USA \\ ${ }^{7}$ Institute of Arctic Biology, University of Alaska Fairbanks, Fairbanks, Alaska 99775-7000, USA
}

\begin{abstract}
As central-place foragers, seabirds from colonies located close to multiple and/or productive marine habitats might experience increased foraging opportunities and enhanced resilience to food shortages. We tested whether this hypothesis might explain divergent trends in 3 populations of black-legged kittiwakes Rissa tridactyla, a surface-feeding piscivore, in the eastern Bering Sea. We simultaneously studied the foraging behavior, diet, nutritional stress, and breeding performance of chick-rearing kittiwakes from 2 continental shelf colonies (St. Paul and St. George) and an oceanic colony (Bogoslof). Although shelf-based forage fishes were rare or absent in bird diets during the cold study year, not all kittiwakes from the 3 colonies concentrated foraging along the productive shelf break habitats. Compared to the oceanic colony, birds from both shelf-located colonies had lower chick provisioning rates, higher levels of nutritional stress, and lower breeding performance. Although birds from both shelf-based colonies foraged in nearby neritic habitats during daytime, birds from St. George, a stable population located closest to the continental shelf break, also conducted long overnight trips to the ocean basin to feed on lipid-rich myctophids. In contrast, birds from St. Paul, a declining population located farthest from shelf break/oceanic habitats, fed exclusively over the shelf and obtained less high-energy food. Birds from Bogoslof, an increasing population, foraged mainly on myctophids close to the colony in the oceanic basin and Aleutian coast habitats. Our study suggests that proximity to multiple foraging habitats may explain divergent population trends among colonies of kittiwakes in the southeastern Bering Sea.
\end{abstract}

KEY WORDS: GPS tracking - Foraging strategies $\cdot$ Marine habitats $\cdot$ Kittiwakes $\cdot$ Productivity · Diet $\cdot$ Nutritional stress $\cdot$ Bering Sea $\cdot$ Seabird populations

Resale or republication not permitted without written consent of the publisher

\section{INTRODUCTION}

Central-place foragers are constrained by the need to feed their offspring (Orians \& Pearson 1979); therefore, close proximity to high-quality food is expected to balance foraging costs during reproduction (Mac-
Arthur \& Pianka 1966). Distance to abundant or highquality food sources has been shown to be an important determinant of animal's foraging decisions (Rainho \& Palmeirim 2011), and fitness payoffs usually measured as net energy gain (Naef-Daenzer 2000) and reproductive success (Suryan et al. 2000). Bal- 
ancing resource allocation between reproductions is particularly important for long-lived animals (Williams 1966), such as seabirds, because excessive effort allocation in a current reproduction can strongly affect adult survival (Stearns 1992). Seabirds adopt different foraging strategies to cope with changes in prey availability in the vicinity of their colonies by shifting to less preferred prey (Bryant et al. 1999, Mullers et al. 2009), increasing foraging range and time at sea (Suryan et al. 2000, Boersma \& Rebstock 2009), or alternating short and long trips to balance the energy requirements of chicks and adults (Saraux et al. 2011). Such changes in the allocation of foraging effort (energy and time) and diet quality (Kitaysky et al. 2006, Romano et al. 2006) appear to be sometimes costly for both offspring (Golet et al. 2000) and adults (Oro \& Furness 2002, Harding et al. 2011). Physiologically, foraging seabirds respond to a decrease in food availability with increasing levels of nutritional stress (as measured by the hormone corticosterone; Kitaysky et al.1999, 2010, Dorresteijn et al. 2012), poor reproduction (Buck et al. 2007), or lower survival rates (Goutte et al. 2010). Chronic reductions in food availability have been shown to affect both reproductive (Cury et al. 2011) and population vital rates (Irons et al. 2008, Satterthwaite et al. 2012) in seabirds.

Predictability of prey aggregations differs spatially and temporally across marine habitats; neritic waters of continental shelves are more often used by seabirds (Weimerskirch 2007) and considered more productive than oceanic waters in the basin (Huyer 1983, Springer et al. 1996a, Brown et al. 2011). Yet, the availability of prey for seabirds on shelf habitats may become less stable (Einoder et al. 2011) and less predictable over long-term scales compared to basin habitats (Weimerskirch 2007). The location of seabird colonies close to predictable productive habitats (Croxall \& Wood 2002, Laidre et al. 2008), coupled with the repetitive use of oceanographic features by chick-rearing birds (Irons 1998, Weimerskirch 2007), highlight the importance of anticipated prey in the selection of breeding habitat. Long-term analysis of stable isotopes indicates that the stable population of snare penguins Eudyptes robustus appeared to benefit from stable prey availability over $120 \mathrm{yr}$ as a function of the oceanographic setting of their breeding habitat (Mattern et al. 2009). Although considerably more stable and predictable than the open ocean, the prey assemblies associated with oceanographic features could also vary with annual changes in productivity due to ocean conditions (Zainuddin et al. 2006, Mizobata et al. 2008, Brown et al. 2011).
Hence, proximity of colonies to multiple high-quality marine habitats may be important for central-place foragers when preferred prey is reduced.

Marine ecosystems can be additionally stressed by human activities due to intense fisheries (Jackson et al. 2001) or the warming effects of climate change (Grebmeier et al. 2006). The southeastern continental shelf of the Bering Sea sustains one of the largest fisheries in the United States (Ianelli et al. 2009), and has exhibited extreme variability in sea ice extent, temperature, and the distribution and abundance of species at multiple trophic levels over the past 4 decades (Hunt et al. 2011, Stabeno et al. 2012). Here, seabird colonies at the Pribilof Islands, St. Paul, and St. George have experienced negative or neutral changes in population size over the last $30 \mathrm{yr}$ (Byrd et al. 2008b), contrasting with the positive trajectories of colonies at Bogoslof Island, located in the deep basin north of the Aleutian Arc. Neritic waters surrounding the Aleutian Islands are influenced by oceanic waters from both the Bering Sea and Pacific Ocean, creating a unique habitat (Ladd et al. 2005) likely to respond differently to changes in ocean conditions on the shelf (Aydin et al. 2007). For example, concurrent reductions of key forage fish species, such as capelin Mallotus villosus and juvenile walleye pollock Theragra chalcogramma, in diets of piscivorous seabirds at the Pribilof Islands (Sinclair et al. 2008, Renner et al. 2012) have not been observed at seabird colonies of the Aleutian Islands (Springer et al. 1996b). It has been proposed that differences in seabird population trajectories between shelf- and oceanic-located colonies in the Bering Sea reflect differences in food availability between regions (Byrd et al. 2008b) and/or differences in the proximity or breeding colonies to the productive shelf breaks (Schneider \& Hunt 1984). Seabirds on St. George and Bogoslof have had neutral or positive population trends, and both colonies are located 3 times closer $(\sim 30 \mathrm{~km})$ than St. Paul (declining population) to the productive continental and Aleutian shelf breaks, respectively (Springer et al. 1996a, Ladd et al. 2005). Despite some evidence that supports these predictions (Hunt et al. 2008, Satterthwaite et al. 2012), information on where breeding birds from each colony forage has been unknown prior to the present study, precluding links to reproductive and population processes.

We tested the hypothesis that seabird colonies located close to multiple types of marine habitats have more foraging options and should therefore be more resilient to low local prey availability than colonies with access to fewer marine habitats. We used data from 2009 on the foraging ecology 
Fig. 1. Rissa tridactyla. Foraging trips of GPStracked black-legged kittiwakes nesting at $2 \mathrm{Be}$ ring Sea shelf colonies (St. Paul, St. George) and 1 oceanic colony (Bogoslof) according to time of day: day trips (yellow) were between 05:45 and 23:00 h and overnight trips (blue) were between 23:01 and 05:44 h (based on sunrise/sunset times). The shelf break is indicated by the $200 \mathrm{~m}$ isobath

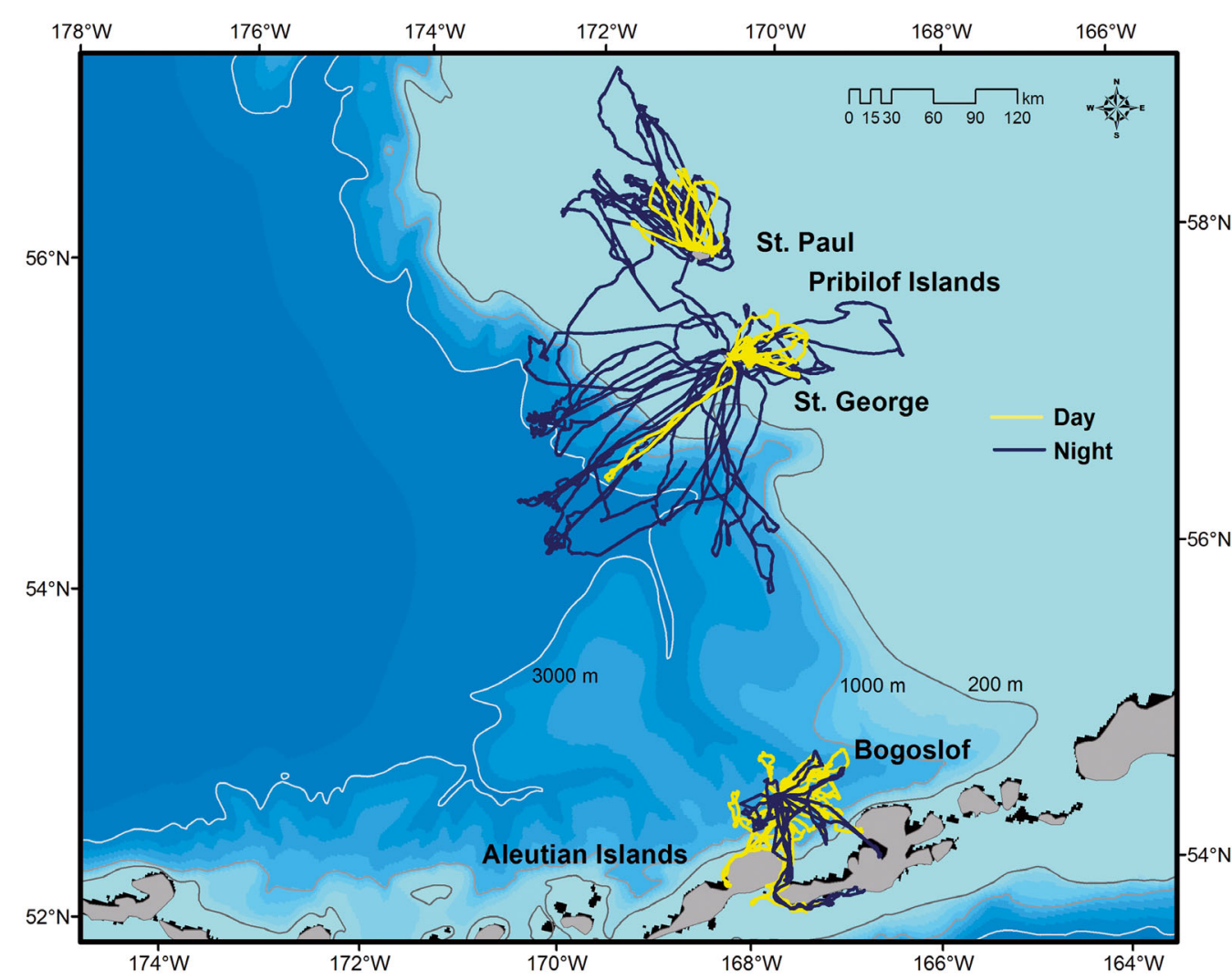

\section{MATERIALS AND METHODS}

(tracking and diet), physiological stress (corticosterone hormone, CORT), and breeding performance of a surface feeder, the black-legged kittiwake Rissa tridactyla, nesting at 3 Bering Sea colonies with different oceanographic locations and population trajectories: St. George, St. Paul, and Bogoslof Island. Previous studies at the Pribilof Islands have shown that in cold years piscivorous seabirds have reduced reproductive success because of low availability of key forage fish on the continental shelf (Benowitz-Fredericks et al. 2008, Satterthwaite et al. 2012). Since 2009 was a cold year on the southeastern Bering Sea shelf (Hunt et al. 2011, Stabeno et al. 2012), we predicted: (1) St. Paul birds (declining population and located farthest from the continental shelf break) would have longer foraging distances, resulting in higher levels of nutritional stress, and lower breeding performance; (2) St. George birds (stable population and located closer to the continental shelf break) would have shorter foraging distances, lower levels of nutritional stress, and moderate breeding performance; and (3) Bogoslof birds (increasing population and located closer to the Aleutian shelf break and oceanic basin) would travel shorter distances and show lower levels of nutritional stress and higher breeding performance.

\section{Study site and species}

We studied kittiwakes Rissa tridactyla simultaneously at 3 island colonies in 2009: the Pribilof Islands, St. Paul $\left(104 \mathrm{~km}^{2}, 57^{\circ} 7^{\prime} \mathrm{N}, 170^{\circ} 17^{\prime} \mathrm{W}\right)$ and St. George $\left(90 \mathrm{~km}^{2}, 56^{\circ} 36^{\prime} \mathrm{N}, 169^{\circ} 33^{\prime} \mathrm{W}\right)$ in the southeastern Bering Sea, and Bogoslof Island $\left(1.28 \mathrm{~km}^{2}, 53^{\circ} 55^{\prime} \mathrm{N}\right.$, $168^{\circ} 02^{\prime} \mathrm{W}$ ) in the central-eastern Bering Sea (Fig. 1). Fieldwork was conducted from the mid-incubation period to the end of the chick-rearing period at all 3 colonies, from 19 June to 30 August.

The last population count undertaken at Bogoslof Island in 2005 estimated a total population size of 15000 kittiwakes (including a few red-legged kittiwakes Rissa brevirostis; Renner \& Williams 2005). The total population of black-legged kittiwakes at St. Paul ( 15000 individuals) and St. George ( 72000 individuals) for the same year was calculated based on counts by Hickey \& Craighead (1977) and trend rates reported by Byrd et al. (2008b). Kittiwakes on the Pribilof Islands have no major avian predators, whereas glaucous-winged gulls Larus glaucescens are common nest predators at Bogoslof. Kittiwakes feed primarily on 3 forage fish species: juvenile pollock, myctophids (Myctophidae), and sandlance 
(Ammodytidae) at all 3 islands (Iverson et al. 2007, Sinclair et al. 2008).

Cold conditions characterized the study year (Stabeno et al. 2012), with an overall low abundance of juvenile pollock on the southeastern Bering Sea continental shelf and in the Bogoslof Island region (Ianelli et al. 2009). Although both juvenile stages of pollock (age-0 and age-1) were present, young-ofthe-year were predominant in surveys conducted near the Pribilof Islands, and patches were mostly found in the deep sections of the water column (Benoit-Bird et al. 2011). During bottom trawl surveys of groundfish by the Resource Assessment and Conservation Engineering Division (RACE), other forage fish species, such as capelin and sandlance, were poorly represented near the Pribilof Islands during June and July 2009 (Lauth 2010).

\section{Field data collection}

Sixty-two adult kittiwakes raising chicks 5 to $25 \mathrm{~d}$ old were captured at the nest site for deployment of data loggers using both $8 \mathrm{~m}$ noose poles and snare traps from below the nest and foot snare traps from the top of cliffs. Captured birds were bled for subsequent CORT analysis, weighed using a $500 \mathrm{~g}$ Pesola balance $( \pm 5 \mathrm{~g})$, banded with a U.S. Fishery and Wildlife Service (USFWS) metal band, affixed with loggers, and temporally marked with livestock paint to facilitate individual identification. All birds were sampled according to a standardized technique (Benowitz-Fredericks et al. 2008), with a blood sample $(<100 \mu l)$ collected from the brachial vein within 3 min of capture, which is required to obtain baseline levels of corticosterone in kittiwakes (Kitaysky et al. 1999). Samples were centrifuged, and plasma was stored frozen for later analysis of baseline levels of CORT at the University of Alaska Fairbanks. Global positioning system (GPS) data loggers (Gipsy 3-Technosmart; flat antenna with a $250 \mathrm{~mA}$ battery; size = $41 \times 14 \times 7 \mathrm{~mm}$; weight $=10$ to $12 \mathrm{~g}$ ) were attached to the dorsal surface of 4 central rectrices using white Tesa tape@ No. 4651. GPS loggers were encapsulated in a shrink tube casing $(2 \mathrm{~g} ; 4$ FT IC8725 3/4 inch $(19 \mathrm{~mm})$ thick clear; Frigid North) prior to deployment to ensure waterproofing. GPS loggers recorded latitude and longitude, time and date, speed, and altitude at a 1 or $180 \mathrm{~s}$ sampling interval. Activity loggers (British Antarctic Survey; Mk13: weight $=1.8 \mathrm{~g}$; MK9: weight $=2.5 \mathrm{~g}$ ) attached to plastic color legbands were simultaneously deployed on all GPS birds. The activity logger recorded saltwater immer- sions every $3 \mathrm{~s}$, and data were stored as the proportion of each 10 min period ranging from completely dry (0) to completely wet (200). Total instrument weight was $3.6 \%$ of average kittiwake body mass at the 3 colonies $(411 \pm 6.0 \mathrm{~g}, \mathrm{n}=54)$. Recapture effort started $2 \mathrm{~d}$ after deployment, and the majority of birds $(89 \%)$ were recaptured within 2 to $4 \mathrm{~d}$ (Bogoslof: $2.25 \pm 0.04 \mathrm{~d}_{i}$ St. Paul: $2.24 \pm 0.04 \mathrm{~d}_{i}$ St. George: $2.94 \pm 0.05 \mathrm{~d})$, although a few birds $(\mathrm{n}=6)$ were recaught up to $15 \mathrm{~d}$ later. Upon recapture, devices were retrieved, birds were bled and weighed again, diet samples were collected, and standard body measurements (culmen, wing cord, tarsus, and head-bill) were taken using calipers and stopped rulers $( \pm 0.01 \mathrm{~mm})$. An additional drop of blood was collected for DNA analysis of sex determination (Fridolfsson \& Ellegren 1999). Diet samples were collected from both regurgitations of captured adults or chicks, and the stomach contents of adults were obtained using the water-offloading method (Wilson 1984). Each bird was flushed twice to ensure that most of the stomach content was obtained (see Renner et al. 2012 for details). Diet samples were weighed using a $100 \mathrm{~g}$ balance $( \pm 1 \mathrm{~g})$ immediately after collection and preserved with $70 \%$ ethanol for laboratory analysis. Additional chick-rearing birds were captured once following the same capture procedure as tagged birds in order to increase the number of diet samples at each colony (St. Paul: $\mathrm{n}=17$; St. George: $\mathrm{n}=7$; Bogoslof: $\mathrm{n}=18$ ) and CORT (St. Paul: $\mathrm{n}=16$; St. George: $\mathrm{n}=21$; Bogoslof: $\mathrm{n}=13$ ). Birds were handled on average $15 \pm 1$ min (range: 5 to $30 \mathrm{~min}$ ) at initial capture and an average of $30 \pm$ $1 \mathrm{~min}$ (range: 13 to $45 \mathrm{~min}$ ) at recapture. Most birds $(74 \%, \mathrm{n}=62)$ returned to the nest within $15 \mathrm{~min}$ of their release, and the remaining individuals returned within $40 \mathrm{~min}$.

A subset of nests ( $\mathrm{n}=10$ to 12 ) with non-instrumented birds was observed from dawn to dusk (06:00 to $23: 30 \mathrm{~h}$ ) during a total of 3 to $6 \mathrm{~d}$ at all 3 colonies. Observations were conducted during early, mid-, and late chick rearing to account for any difference in provisioning behavior associated with chick age. Times of all adult arrivals, departures, and chick feeds were recorded to determine both chick-feeding frequency and forage-trip durations at each colony.

\section{Laboratory and data analysis}

Our multipronged study includes the following data analyses: (1) foraging behavior-GPS and activity-logger tracking (trip distance and duration), 
azimuth (compass direction or bearing), and at-colony observations of non-tagged birds (trip duration and chick feeding frequencies); (2) diet composition; (3) nutritional stress levels (CORT); and (4) breeding parameters (breeding and fledging success).

Effect of instrumentation was addressed by comparing: (1) the trip duration of tagged and control birds and (2) the stress levels of birds before and after logger deployment (Tremblay et al. 2003). We used published data on juvenile pollock abundance and distribution (Benoit-Bird et al. 2011) collected during the same time as the colony study period for interpreting bird foraging patterns.

\section{Foraging behavior}

GPS and activity-logger tracking. Location data from GPS units were first filtered following a forward-backward speed method (McConnell et al. 1992). We used a maximum speed of $80 \mathrm{~km} \mathrm{~h}^{-1}$ (the maximum instantaneous velocity recorded from the highest quality GPS fixes [dilution of precision of 1 , indicating a wider angular separation of satellites and the highest positional accuracy] was $71 \mathrm{~km} \mathrm{~h}^{-1}$ ) to cull erroneous positions (median: $5 \%$, range: 0 to $19 \%$, of locations were removed from each individual), leaving approximately 352500 locations from 53 individuals. Most of the erroneous locations were near the colony, likely due to satellite signal interference from adjacent rock cliffs or vegetation. Not all GPS units recorded positions at the same time intervals, and some units occasionally malfunctioned with larger time gaps in obtaining positions. Due to these complications, we spatially interpolated all tracking data at $10 \mathrm{~m}$ linear intervals for time gaps of $30 \mathrm{~min}$ or less between consecutive locations. Of the trips $23 \%$ were considered incomplete for calculating duration, and $14 \%$ of the trips were incomplete for calculating distance.

We developed an automated routine using Matlab (Mathworks) to identify and measure central-place foraging trips (distance, duration, and azimuth) based on specific criteria. We defined a foraging trip based on the activities of birds carrying GPSs and on direct observations of adults returning with prey to provision chicks. These criteria required a bird to leave a $0.5 \mathrm{~km}$ buffer around the nest site for a minimum of 30 min (the lower 25th percentile of observed foraging trip durations at all islands) to be included in analyses of foraging activity. We measured the straight-line distance and calculated the azimuth between the nest site and the most distant location of each central-place trip. In situations where a complete round-trip was not recorded because of GPS failure before the bird returned to the colony, we only included the maximum distance estimate in our analyses if the individual returned to within $75 \%$ of the maximum distance from the colony before the track was lost. The bird had to return to within $1 \mathrm{~km}$ of the colony for a trip to be considered complete and to be included in calculations of trip duration. A night trip ( $n=115)$ was defined as either beginning on one calendar day and returning the next $(87 \%)$, or departing and returning on the same day between sunset and midnight or between midnight and sunrise $(13 \%)$. Daily times of sunrise and sunset at each island were obtained from the Astronomical Applications Department, U.S. Naval Observatory, Washington, DC. Trip distance and duration were analyzed using general linear mixed models (GLMM), with colony, sex, and time of day (day and overnight) as the main factors and individual included as a random factor. For analysis of frequencies of habitat use, all trips per island were categorized according to the farthest point of a track overlapping 1 of 4 marine habitats: shelf ( 25 to $200 \mathrm{~m}$ depth), shelf break (200 to $1000 \mathrm{~m})$, oceanic basin (>1000 m depth), and the Aleutian coast. Roseate plots were used to summarize frequencies of trip direction among colonies.

For the kernel density analysis and activity budgets, we linked activity-logger data (wet/dry values) to the nearest actual or interpolated bird location using GPS data, allowing a time lag of $8 \mathrm{~min}$ previous and 2 min following the activity record. The first 10 min time period recorded after an individual left the nest was negated, since birds were commonly observed bathing or visited ponds after leaving their nest site. Three at-sea activity types were defined: flying, resting, and 'active foraging'. Flying was defined as when the logger was dry for at least $99 \%$ of a given 10 min interval when a bird was away from the nest. Resting on the water was defined as when a bird spent $90 \%$ or greater of its time on the water during a given $10 \mathrm{~min}$ interval, and this $10 \mathrm{~min}$ interval was associated with previous and subsequent 10 min bins where $90 \%$ or more of the time was spent on the water and by being completely wet for a 10 min interval. This allows for some activity to occur that might cause a logger to record dry such as bathing and preening during prolonged periods of sitting on the water. 'Active foraging' was defined as all other times spent at sea, which constituted periods when birds were switching states between air and water. A GLMM, using individual as a random factor, was used to analyze differences in at-sea activities 
among colonies and time of day. Most trips (92\%; $\mathrm{n}=119$ ) that were categorized as foraging trips by the central-place analysis (GPS data only) had 'active foraging', and those that did not were excluded from the analysis. Kernel densities of 'active foraging' locations were used to graphically display foraging range (95 and $75 \%$ contours) and core feeding areas (50\% contours). The smoothing factor or bandwidth $(14651.51 \mathrm{~m})$ and raster cell size $(100 \mathrm{~m})$ of the bivariate kernels were calculated using ArcGIS and Home Range Tools.

At-colony observations. Only trips that resulted in a chick-feed were included in estimates of forage trip duration. These trips were compared with daytime trips of instrumented birds to address possible effects of instrumentation using a GLMM with colony as a fixed factor and individual as a random factor. We found no significant difference in the average trip duration between controls $\left(3.8 \pm 0.2 \mathrm{~h}_{i} \mathrm{n}=220\right)$ and instrumented birds $\left(4.7 \pm 0.4 \mathrm{~h} ; \mathrm{n}=74 ; F_{1,288}=1.178\right.$, $\mathrm{p}=0.279)$ regardless of colony $\left(F_{2,288}=2.150, \mathrm{p}=\right.$ 0.118 ). Chick-meal delivery rates by non-instrumented birds, calculated as the number of feeds delivered per hour at each nest, were compared among colonies using ANOVAs to examine differences in foraging performance.

\section{Diet composition}

Prey items were identified to the lowest taxonomic level possible, and lengths of partially digested pollock were estimated from otolith size to determine age-classes (see Renner et al. 2012). Both adult and chick diets were combined for the analysis (e.g. Jodice et al. 2006a) because adults store prey in their crops for several hours before regurgitating to their young.

Frequency of occurrence was calculated as the percentage of all samples containing prey remains in which a prey item occurred for each colony, and percent biomass was calculated by dividing the sum of the biomass of a particular prey from all samples by the total biomass for all samples combined. We also calculated the net energy content of each diet sample in order to quantify diet quality and compare the mean values among colonies using ANOVAs. For this, energy density values $\left(\mathrm{kJ} \mathrm{g}^{-1}\right)$ for each wet food item were estimated from values in the literature (see Table 3) and multiplied by biomass, and all prey items were summed to obtain the estimated energy content per sample (kJ). Prey items were separated into 3 sub-groups (fish, invertebrates, and fish offal) for calculation of contribution of prey type to the total energy content. Fish offal or processor waste was typically comprised of fish innards, such as livers, intestines, and greasy fat. Diet data from 14 GPStagged birds were collected to relate prey species to foraging habitat. For this analysis, we only included diet samples where GPS units were still recording at time of recapture.

\section{Corticosterone}

CORT concentrations $\left(\mathrm{ng} \mathrm{ml} \mathrm{m}^{-1}\right)$ were measured using radioimmunoassay (Kitaysky et al. 1999). Briefly, each sample was equilibrated with $2000 \mathrm{cpm}$ of tritiated CORT prior to extraction with $4.5 \mathrm{ml}$ distilled dichloromethane. After extraction, percent tritiated hormone recovered from each individual sample (average hormone recovery was $>87 \%$ ) was used to correct final CORT concentrations. Samples (in duplicates) were reconstituted in phosphate-buffered saline gelatin buffer and combined with antibody and radiolabel in a radioimmunoassay. Dextrancoated charcoal was used to separate antibodybound hormone from unbound hormone. All samples were analyzed in 5 different assays; sensitivity of the assays was $7.8 \mathrm{pg} \mathrm{tube}^{-1}$; and inter-and intra-assay variations were $<6$ and $2 \%$, respectively.

Comparison of the CORT levels of tagged birds at capture and recapture indicated no effect of instrumentation at any of the colonies (paired $t$-tests: $\mathrm{p}$-values $>0.081$ ). Therefore, to compare nutritional stress levels among colonies (Kitaysky et al. 2007, 2010) we used all CORT samples taken at both capture and re-capture in a GLMM with individual as a random factor.

We also conducted a general linear model (GLM) analysis of trip distance (response variable) using colony, body condition, and CORT as explanatory variables to examine whether foraging effort was affected by adult condition and CORT at deployment (details presented in Appendix 1). Sample sizes were limited, but we did not find a significant effect of any of the independent variables on trip distance (Appendix 1).

\section{Breeding parameters}

We used breeding success as another indicator of food availability and fledgling success as a proxy of foraging performance (Piatt et al. 2007). Between 6 and 16 plots of kittiwakes, each with 7 to 38 nests, 
were monitored every 3 to $5 \mathrm{~d}$ from the mid-incubation period through to the end of chick-rearing, following Alaska Maritime National Wildlife Refuge protocols (USFWS 1997). Breeding success (chicks fledged per nest with eggs) and fledgling success (chicks fledged per nest with chicks; see Byrd et al. 2008a) were calculated for each island and then compared among islands using ANOVAs.

\section{Statistical analysis}

Statistical analysis was carried out using PASW Statistics 18 and R. We used parametric tests (ANOVAs, GLMs \& GLMMs, and paired $t$-tests) to compare groups if the residuals met the assumptions for the GLMs (i.e. homogeneity, independence, normality, and constant variance). Multiple comparisons were undertaken using Tukey post hoc tests unless otherwise indicated. We used Chi-squared tests with Yates correction for comparing frequencies of trips for habitat use and activity budgets. Means were expressed ( \pm standard error of the mean). All comparisons were 2-tailed, and differences were considered significant when $\mathrm{p} \leq 0.05$.

\section{RESULTS}

\section{General foraging behavior}

Of the 62 black-legged kittiwakes Rissa tridactyla with data-loggers deployed, 7 were not recovered due to chick mortality $(\mathrm{n}=4)$ and unknown causes $(\mathrm{n}=3)$. Foraging parameters were obtained from a total of 47 birds (Table 1). On average, the distance and duration of individual kittiwake trips recorded was $55.3 \pm 4.5 \mathrm{~km}$ (range $=1.9$ to $195 \mathrm{~km}, \mathrm{n}=115$ ) and $8.1 \pm 1.1 \mathrm{~h}$ (range $=0.8$ to $41.4 \mathrm{~h}, \mathrm{n}=99$ ), respectively. At-colony observations of non-instrumented birds indicated differences in provisioning rates among colonies $\left(F_{2,42}=7.156, \mathrm{p}=0.002\right)$; Pribilof chicks were fed less often than Bogoslof chicks (post hoc test: $\mathrm{p}<0.02$ ). Meal delivery rates did not differ significantly between the 2 Pribilof Islands $(p>0.05$; see Fig. 4A).

\section{Diurnal patterns in foraging behavior}

The 2 GLMMs of trip distance and trip duration indicate no significant interactive effects of colony and time of day with sex ( $p>0.05)$. On average, female kittiwakes made significantly longer distance (female: $64.8 \pm 6.7 \mathrm{~km}, \mathrm{n}=49$; male: $48.3 \pm 5.9 \mathrm{~km}$, $\left.\mathrm{n}=66 ; F_{1,103}=6.026, \mathrm{p}=0.016\right)$ and longer duration (female: $9.2 \pm 1.3 \mathrm{~h}, \mathrm{n}=40$; male: $7.3 \pm 0.7 \mathrm{~h}, \mathrm{n}=59$; $\left.F_{1,87}=4.566, \mathrm{p}=0.035\right)$ trips than males. In contrast, both trip parameters were affected by time of day and colony (distance: $F_{2,103}=19.09, \mathrm{p}<0.0001$; duration: $F_{2,87}=3.517, \mathrm{p}=0.034$; Table 2). Birds at the Pribilofs had a bimodal foraging strategy, with longer distance overnight trips and shorter distance daytime trips (St. Paul: $F_{1,36}=12.960, p=0.001$; St. George: $\left.F_{1,39}=58.464, \mathrm{p}<0.0001\right)$. Birds from Bogoslof did not adjust their trip distances with time of day $\left(F_{1,34}=\right.$ 0.069, $\mathrm{p}=0.794$; Table 2). During the day, kittiwakes foraged near the islands, and there was no difference in distance traveled among colonies $\left(F_{2,71}=2.259, \mathrm{p}=\right.$ $0.112)$. There were differences, however, in overnight trip distance traveled among colonies $\left(F_{2,38}=\right.$ 12.951, p < 0.0001). St. George kittiwakes traveled greater distances than both St. Paul (post hoc test: $\mathrm{p}<0.001$ ) and Bogoslof (post hoc test: $\mathrm{p}<0.0001$ ), whereas there was no difference in overnight trip distance between birds from St. Paul and Bogoslof (post hoc test: 0.313; Table 2). Similarly, the durations of daytime trips conducted at the 3 colonies were comparable $\left(F_{2,61}=8.878, \mathrm{p}=0.162\right)$. Although results were only marginally significant for overnight trips $\left(F_{2,32}=3.316, \mathrm{p}=0.049\right)$, St. George birds also tended to have longer trip durations than their coun-

Table 1. Summary statistics of data-logger deployment and total number of trips obtained at 3 Bering Sea colonies of blacklegged kittiwakes Rissa tridactyla

\begin{tabular}{|lccc|}
\hline & St. Paul & St. George & Bogoslof \\
\hline Birds with GPS/activity data-loggers deployed & 19 & 23 & 20 \\
Data-logger units recovered & 17 & 21 & 17 \\
Data-logger units with sufficient data for analysis & 14 & 19 & 14 \\
Bird abandoned/nest failed & 2 & 31 & 36 \\
No. of trips - max. distance attained & 38 & 35 & 30 \\
No. of trips - complete (duration) & 34 & 2 & \\
\hline
\end{tabular}


Table 2. Rissa tridactyla. Diurnal differences in foraging habitat, trip distance, and trip duration of black-legged kittiwakes nesting at shelf and oceanic colonies. Foraging habitat: total number of trips (St. Paul $=38$, St. George $[\mathrm{SG}]=41$, Bogoslof $=36$ ) for calculation of percentages $(\%)$. Data are means $( \pm \mathrm{SE}$, with $\mathrm{n}$ in parentheses); bold print indicates significance at $\mathrm{p}<0.05$

\begin{tabular}{|c|c|c|c|c|c|c|c|c|c|c|c|}
\hline & \multirow{2}{*}{\multicolumn{6}{|c|}{ Shelf colonies }} & \multirow{2}{*}{\multicolumn{3}{|c|}{$\begin{array}{l}\text { Oceanic colony } \\
\text { Bogoslof }\end{array}$}} & \multicolumn{2}{|c|}{ Among islands } \\
\hline & & & & & & & & & & & \\
\hline & Day & Overnight & $\mathrm{p}$ & Day & Overnight & $\mathrm{p}$ & Day & Overnight & $\mathrm{p}$ & p (day) & $\mathrm{p}$ (night) \\
\hline Distance $(\mathrm{km})$ & $\begin{array}{l}29.1 \pm 4.9 \\
(22)\end{array}$ & $\begin{array}{c}70.5 \pm 11.7 \\
(16)\end{array}$ & 0.001 & $\begin{array}{l}33.5 \pm 6.5 \\
(25)\end{array}$ & $\begin{array}{c}134.5 \pm 13 \\
(16)\end{array}$ & 0.0001 & $\begin{array}{c}44.0 \pm 3.7 \\
(27)\end{array}$ & $\begin{array}{c}46.2 \pm 9.6 \\
(9)\end{array}$ & 0.794 & 0.112 & $\begin{array}{c}<0.001 \\
(\mathrm{SG})^{\mathrm{a}}\end{array}$ \\
\hline Duration (h) & $\begin{array}{l}3.4 \pm 0.5 \\
(19)\end{array}$ & $\begin{array}{l}12.9 \pm 1.6 \\
(15)\end{array}$ & 0.0001 & $\begin{array}{l}5.2 \pm 0.8 \\
(23)\end{array}$ & $\begin{array}{l}18.9 \pm 2.3 \\
(12)\end{array}$ & 0.0001 & $\begin{array}{c}4.6 \pm 0.5 \\
(22)\end{array}$ & $\begin{array}{c}11.8 \pm 2.0 \\
(8)\end{array}$ & 0.001 & 0.162 & $\begin{array}{l}0.049 \\
(\mathrm{SG})^{\mathrm{a}}\end{array}$ \\
\hline \multicolumn{12}{|c|}{ Activity budget (\% time) } \\
\hline Flying & $54 \pm 5$ & $30 \pm 5$ & 0.001 & $51 \pm 5$ & $50 \pm 4$ & 0.905 & $59 \pm 3$ & $31 \pm 6$ & 0.0001 & 0.075 & 0.067 \\
\hline Resting & $5 \pm 1$ & $31 \pm 4$ & 0.0001 & $5 \pm 2$ & $18 \pm 3$ & 0.002 & $1 \pm 1$ & $34 \pm 7$ & 0.0001 & 0.257 & 0.051 \\
\hline Foraging & $41 \pm 4$ & $39 \pm 4$ & 0.740 & $44 \pm 4$ & $32 \pm 3$ & 0.062 & $39 \pm 2$ & $35 \pm 7$ & 0.419 & 0.105 & 0.665 \\
\hline \multicolumn{12}{|c|}{ Foraging habitat ( $\%$ trips) } \\
\hline Shelf break & 0 & 0 & & 0 & 5 & & 2 & 8 & & & \\
\hline Shelf & 60 & 38 & & 18 & 50 & & 0 & 0 & & & \\
\hline Basin & 0 & 2 & & 2 & 25 & & 51 & 8 & & & \\
\hline Aleutian I. coast & 0 & 0 & & 0 & 0 & & 23 & 8 & & & \\
\hline
\end{tabular}

terparts at the 2 other colonies. Overnight trips were longer in duration than daytime trips at all 3 study colonies ( $p<0.001 ;$ Table 2). Analyses of activity budgets show no diurnal differences in the allocation of time spent 'resting' or 'actively foraging' during trips conducted by birds at all 3 colonies $(p>0.05$,
Table 2). Birds from St. Paul and Bogoslof spent proportionately less time 'flying' overnight than during day trips (St. Paul: $F_{1,34}=12.144, \mathrm{p}=0.001$; Bogoslof: $\left.F_{1,34}=23.934, \mathrm{p}<0.0001\right)$. Despite large diurnal differences in trip distance, St. George birds allocated proportionally similar time to 'flying' during daytime

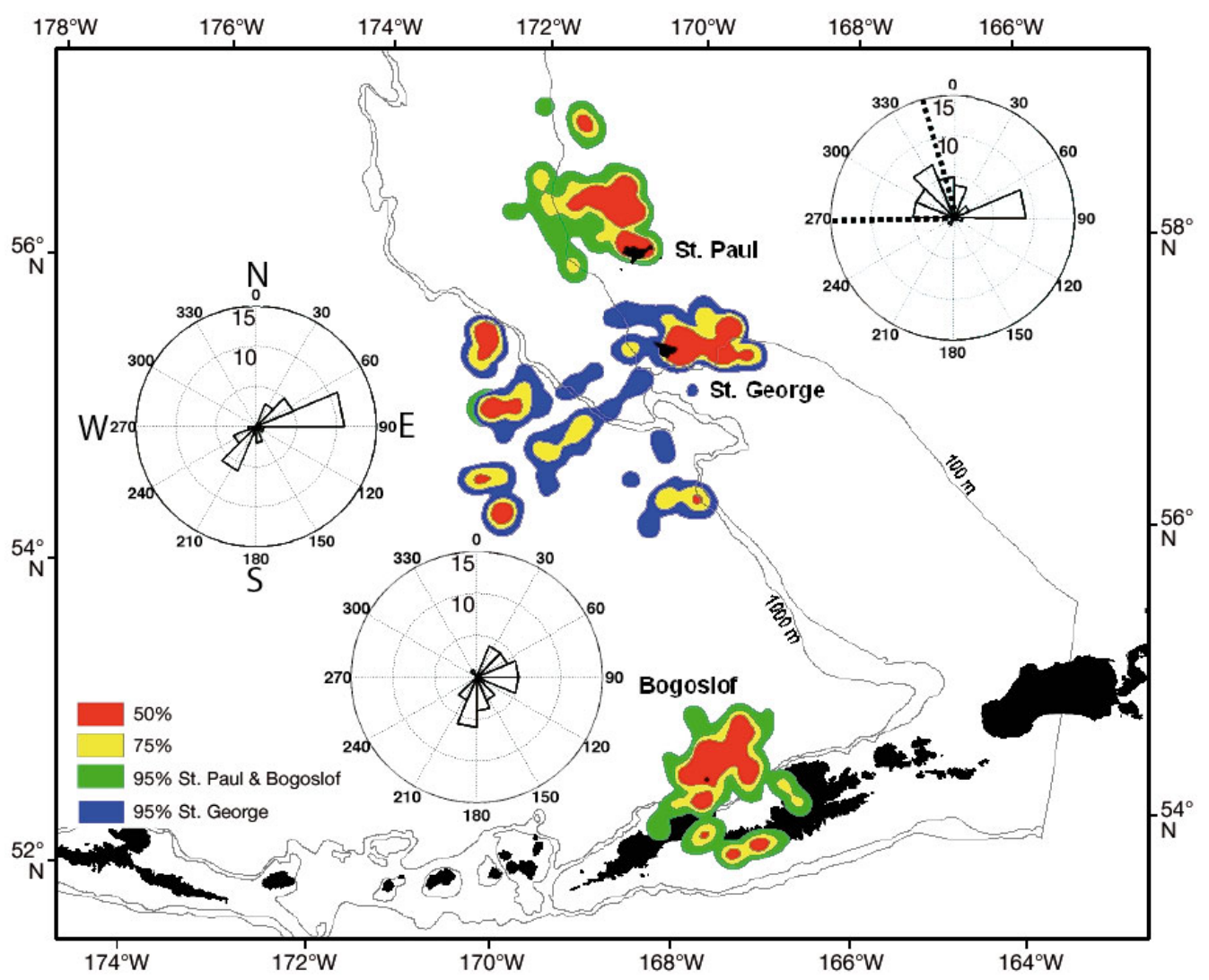

Fig. 2. Rissa tridactyla. Kernel densities of foraging locations of blacklegged kittiwake at 2 shelf colonies (St. Paul $=38$ trips; St. George $=41$ trips) and an oceanic colony (Bogoslof $=36$ trips); percentages of volume contour represent total foraging range $(95 \%$ and $75 \%)$ and core feeding areas (50\%). The rosette plots beside each island show the number of bird tracks (at 5 increments) by azimuths calculated from the nest site to the maximum point of each foraging trip. Dashed lines in the panel for St. Paul indicate the region $\left(270\right.$ to $\left.350^{\circ}\right)$ where patches of juvenile pollock were found 60 to $170 \mathrm{~km}$ from the island by a concurrent ship-based study (Benoit-Bird et al. 2011) 
and overnight trips $\left(F_{1,36}=0.014, \mathrm{p}=0.905\right)$. There were no statistical differences in the 3 at-sea activities among islands ( $p>0.05$; Table 2$)$; however, birds from St. George tended to spend more time 'flying' and less time 'foraging' overnight than birds from the other colonies.

\section{Foraging habitats and core feeding areas}

Kittiwakes from the 3 colonies foraged in different directions and marine habitats: St. Paul birds mostly foraged on the continental shelf during both day and night trips; St. George birds fed on the shelf during daytime and over the basin at night; and Bogoslof birds mostly foraged in the oceanic basin, with some trips to the Aleutian Island coast regardless of time of day (Table 2). The shelf break was not the final destination for a few St. George and Bogoslof birds, but rather a transition zone to access either the oceanic basin or the Aleutian coast, respectively (Table 2, Fig. 1). Directional tracks of St. George birds to the southwest of the colony coincided with core feeding areas found in the oceanic basin, about 30 to $100 \mathrm{~km}$ from the shelf break (Fig. 2). Similarly, tracks of Bogoslof birds to the SW and SE of the colony coincided with core feeding sites found along the Aleutian coast. More than half of St. Paul bird-tracks (total $\mathrm{n}=40$ ) were headed north to west over the shelf (Fig. 2). Most of these trips (64\%) were within the range $(60$ to $170 \mathrm{~km}$ ) of juvenile pollock found by a concurrent study (Benoit-Bird et al. 2011), and occurred overnight $(72 \%)$.

\section{Diet composition}

Fish dominated diets at all 3 study colonies, both in frequency and total biomass (Table 3). Myctophids were the most frequent and abundant prey at both

Table 3. Rissa tridactyla. Diet composition of black-legged kittiwakes nesting in shelf (St. Paul and St. George) and oceanic (Bogoslof) colonies in the Bering Sea in 2009. Dash: unknown value

\begin{tabular}{|c|c|c|c|c|c|c|c|}
\hline & \multirow[b]{2}{*}{$\begin{array}{c}\text { Energy density } \\
\text { (wet mass, } \\
\mathrm{kJ} \mathrm{g}^{-1} \text { ) }\end{array}$} & \multicolumn{2}{|c|}{$\longrightarrow$ St. Paul $\longrightarrow$} & \multicolumn{2}{|c|}{$\longrightarrow$ St. George -} & \multicolumn{2}{|c|}{ Bogoslof } \\
\hline $\begin{array}{r}\text { Ener } \\
(\mathrm{w}\end{array}$ & & $\begin{array}{c}\text { Percent } \\
\text { occurrence } \\
(\mathrm{n}=30)\end{array}$ & $\begin{array}{l}\text { Percent } \\
\text { biomass } \\
(\mathrm{n}=25)\end{array}$ & $\begin{array}{c}\text { Percent } \\
\text { occurrence } \\
(\mathrm{n}=27)\end{array}$ & $\begin{array}{l}\text { Percent } \\
\text { biomass } \\
(\mathrm{n}=26)\end{array}$ & $\begin{array}{c}\text { Percent } \\
\text { occurrence } \\
(\mathrm{n}=30)\end{array}$ & $\begin{array}{c}\text { Percent } \\
\text { biomass } \\
(\mathrm{n}=27)\end{array}$ \\
\hline Fish species & & 60 & 82.5 & 74 & 65.5 & 90 & 92.7 \\
\hline \multicolumn{8}{|c|}{ Juvenile pollock Theragra chalcogramma } \\
\hline Age-1 & $4.73^{\mathrm{a}}$ & 30 & 24.6 & 0 & 0 & 0 & 0 \\
\hline Age-0 & 3.36 & 0 & 0 & 0 & 0 & 0 & 0 \\
\hline Myctophidae & $9.32^{\mathrm{a}}$ & & & & & & \\
\hline Stenobrachius nannochir & & 0 & 0 & 0 & 0 & 30 & 13.9 \\
\hline S. leucopsaurus & & 3.3 & 14.6 & 74.1 & 64.5 & 23.3 & 32.3 \\
\hline Nannobrachium regale & & 0 & 0 & 0 & 0 & 13.3 & 24.7 \\
\hline Myctophid sp. & & 0 & 0 & 0 & 0 & 16.7 & 8.5 \\
\hline $\begin{array}{l}\text { Sandlance } \\
\text { Ammodytes hexapterus }\end{array}$ & $5.06^{\mathrm{b}}$ & 20 & 16.6 & 0 & 0 & 3.3 & 9.4 \\
\hline Eelpout Lycotes spp. & 4.02 & 10 & 11.6 & 0 & 0 & 0 & 0 \\
\hline $\begin{array}{l}\text { Larval atka mackerel } \\
\text { Pleurogrammus monopterygit }\end{array}$ & $4.02^{\mathrm{b}}$ & 3.3 & 4.9 & 0 & 0 & 0 & 0 \\
\hline Unknown gadid & 4.73 & 3.3 & 6.3 & 0 & 0 & 0 & 0 \\
\hline Blenny spp. & $4.72^{\mathrm{c}}$ & 3.3 & 1.3 & 0 & 0 & 0 & 0 \\
\hline Unidentified larval fish & 4.02 & 6.7 & 2.6 & 0 & 0 & 6.7 & 0.2 \\
\hline Capelin Mallotus villosus & $4.84^{\mathrm{b}}$ & 0 & 0 & 0 & 0 & 3.3 & 4.2 \\
\hline Invertebrates & & 10 & 7.3 & 33.3 & 25.7 & 26 & 7.3 \\
\hline Euphausiids Thysanoessa spp. & $5.26^{\mathrm{a}}$ & 3.3 & 6.5 & 29.6 & 23.8 & 13.3 & 7.1 \\
\hline $\begin{array}{l}\text { Amphipods Themisto spp. } \\
\text { \& Lysianassidae }\end{array}$ & $3.52^{\mathrm{a}}$ & 10 & 0.8 & 22.2 & 0.3 & 10 & 0 \\
\hline $\begin{array}{l}\text { Squid Gonatopsis borealis } \\
\text { \& Gonatus spp. }\end{array}$ & $4.75^{\mathrm{d}}$ & 0 & 0 & 11.1 & 1 & 0 & 0 \\
\hline Pandalid shrimp & - & 0 & 0 & 7.4 & 0.6 & 3.3 & 0.1 \\
\hline Unidentified Mollusca & - & 0 & 0 & 0 & 0 & 3.3 & 0 \\
\hline Fish offal & 4.07 & 26.7 & 6.3 & 14.8 & 9.8 & 0 & 0 \\
\hline
\end{tabular}


Table 4. Rissa tridactyla. Mass and energy content of diet samples from black-legged kittiwakes rearing chicks in shelf (St. Paul and St. George) and oceanic colonies (Bogoslof) in 2009. Percentages indicate the contribution of prey groups to net energy values per diet sample

\begin{tabular}{|c|c|c|c|c|}
\hline & St. Paul $(\mathrm{n}=26)$ & St. George $(n=25)$ & Bogoslof $(n=22)$ & $\mathrm{p}$ \\
\hline Total mass per sample (g) & $20 \pm 3.1$ & $18 \pm 2.7$ & $16 \pm 2.3$ & 0.538 \\
\hline Energy content of diet samples $(\mathrm{kJ})$ & $76 \pm 10.8^{\mathrm{a}}$ & $147 \pm 19.5$ & $137 \pm 10.8$ & 0.007 \\
\hline Fish $(\%)$ & 68 & 80 & 90 & \\
\hline Invertebrates (\%) & 8 & 8 & 10 & \\
\hline Fish offal (\%) & 24 & 12 & 0 & \\
\hline
\end{tabular}

Bogoslof and St. George, although the species diversity was greater at Bogoslof (Table 3). St. Paul kittiwakes fed on several fish species including age-1 juvenile pollock (mean fork length: $124.7 \pm 0.29 \mathrm{~mm}$; $\mathrm{n}=13$ ) and sandlance (fork length: 70 to $100 \mathrm{~mm}$ ).
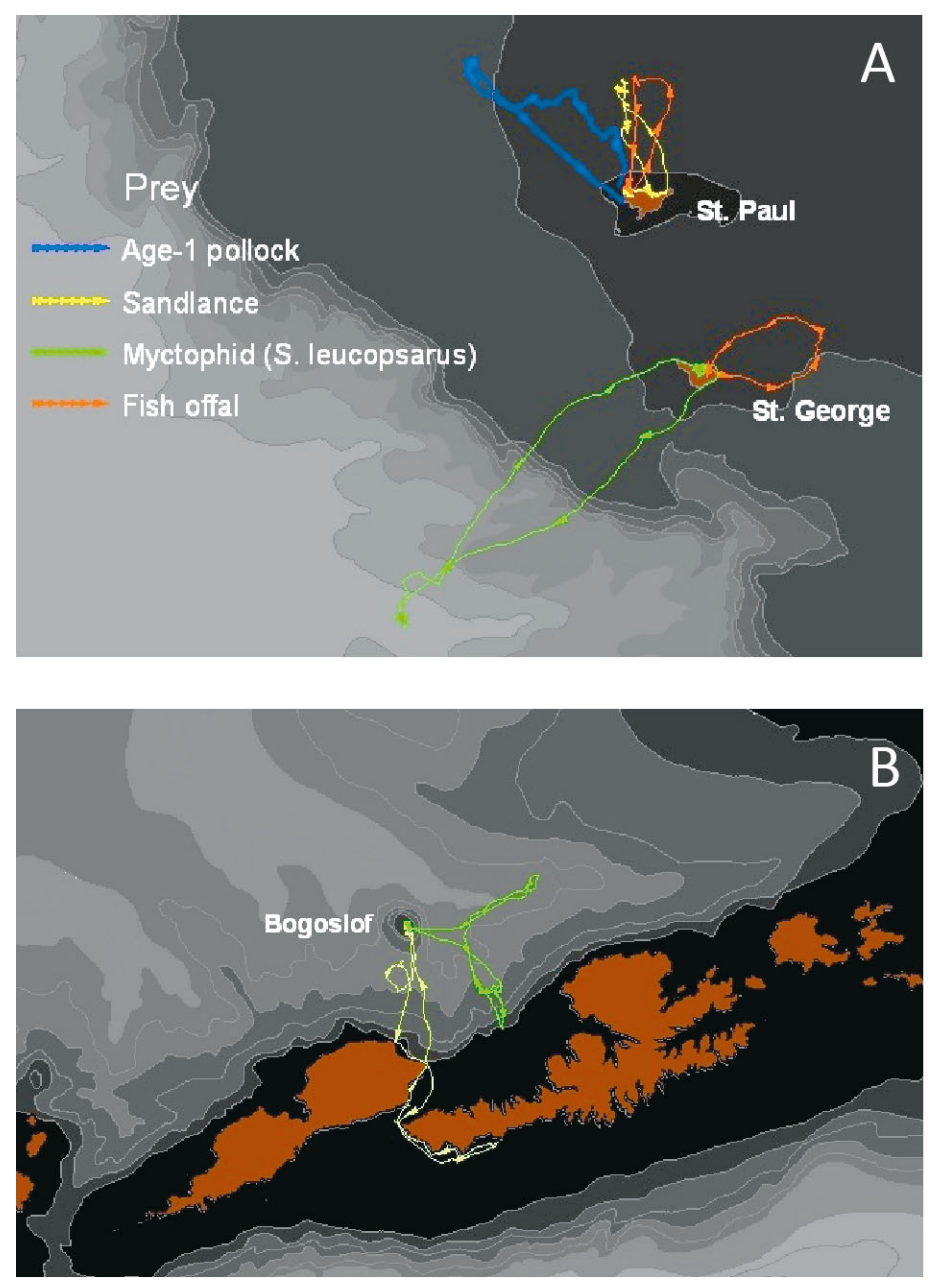

Fig. 3. Rissa tridactyla. Examples of foraging trips with known prey consumed by kittiwakes nesting in shelf colonies (A) and an oceanic colony (B). Fish offal and myctophid (Stenobrachius nannochir, panel B) = day trips; age-1 pollock, sandlance, and myctophid $(S$. leucopsarus, panel A) = overnight trips
Amphipods, euphausiids and squid (Gonatopsis borealis and Gonatus spp.) were found more frequently in St. George diet samples than at either St. Paul or Bogoslof (Table 3). Although the total mass of food per sample did not differ among colonies $\left(F_{2,68}=\right.$ $0.624 ; \mathrm{p}=0.538)$, net energy content per sample differed significantly $\left(F_{2,70}=5.364 ; \mathrm{p}=\right.$ 0.007; Table 4). St. Paul birds had significantly lower energy content per food sample than either St. George (post hoc test: $p=0.009$ ) or Bogoslof (post hoc test: $p=0.037$ ) birds, whereas there was no difference in energy content per food sample between St. George and Bogoslof (post hoc test: $p=0.910$ ). Most of the energy content was attributed to fish at all 3 colonies. Myctophids have the highest energy value of all prey species in this study and contributed to the greater energy content of food consumed by birds at St. George and Bogoslof. Fish offal was the second main contributor to total energy at both shelf colonies, particularly at St. Paul (Table 4).

We were able to link tracking data with prey consumed for single foraging trips of 14 birds. The majority of birds that foraged in the basin fed almost exclusively on myctophids ( $\mathrm{n}=5$ ), and 1 fed on both myctophids and squid. In contrast, birds foraging on the shelf fed on a wider range of prey (age-1 pollock with larvae mackerel Pleurogrammus monopterygius $[\mathrm{n}=1]$, eelpout Lycotes sp. $[\mathrm{n}=1]$, sandlance $[\mathrm{n}=1]$, and fish offal

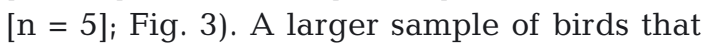
included non-instrumented individuals showed a similar segregation of prey types. In samples containing myctophids, only $32 \%$ also included invertebrates (mostly euphansiids and squid). In samples with pollock, only $34 \%(\mathrm{n}=9)$ included other fish species. In samples with fish offal, only $25 \%(\mathrm{n}=12)$ included other prey. In contrast, inverte- 

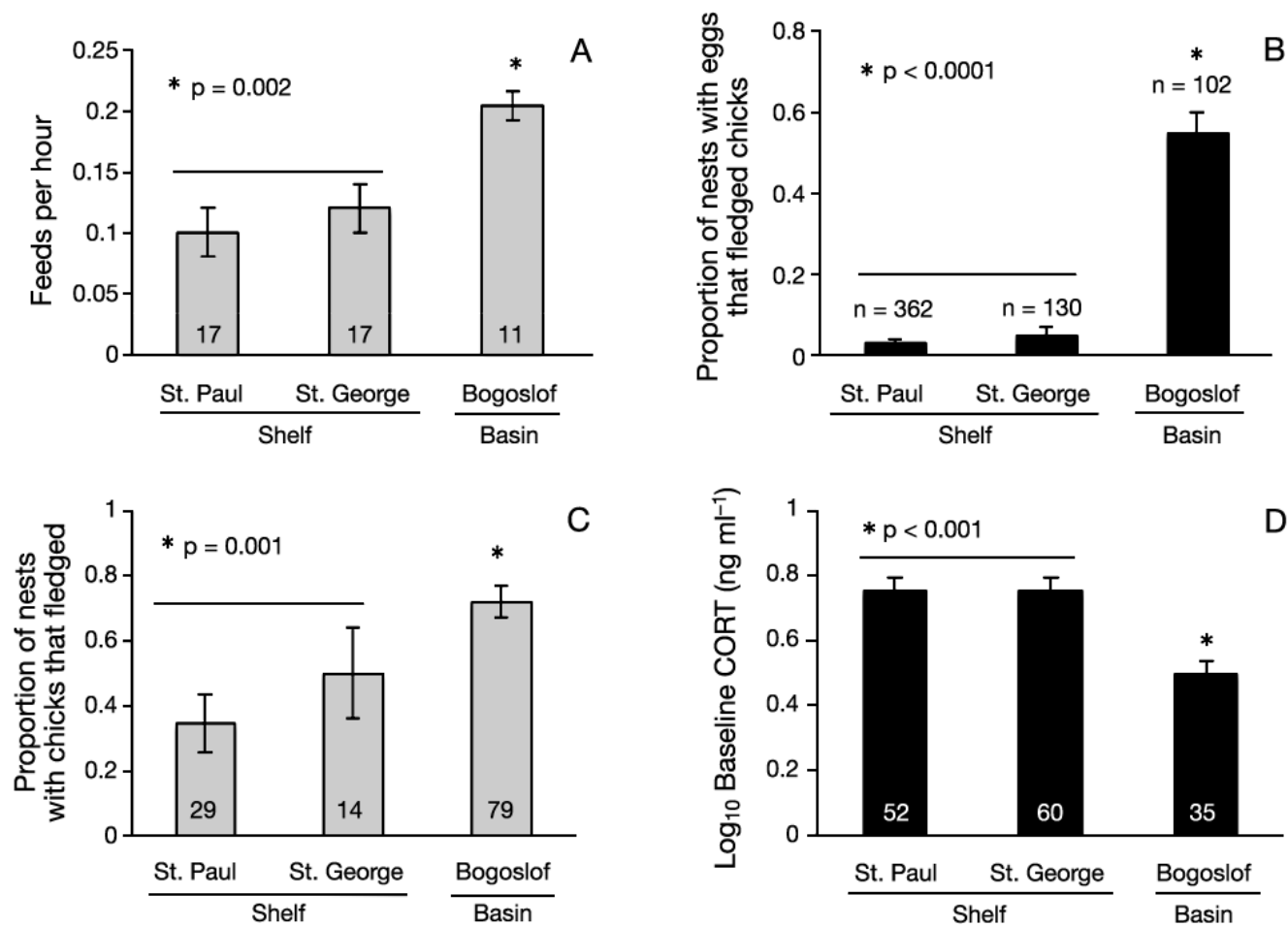

Fig. 4. Rissa tridactyla. Breeding and foraging performance, and stress levels of black-legged kittiwakes at 2 shelf colonies and an oceanic colony (basin) in the Bering Sea 2009: (A) chick feeding frequency, (B) reproductive success, (C) fledging success, and (D) adult stress levels (CORT: corticosterone). Significant (*) and non-significant (bars attached by a horizontal line) differences among colonies indicated. Birds at Bogoslof had higher chick feeding rates, breeding success and lower nutritional stress than birds from both Pribilof Is. (St. Paul and St. George; post hoc tests $p<0.05$ ). Significant differences in fledging success were only found between Bogoslof and St. Paul $(p=0.001)$. There was no significant difference in breeding performance or stress levels between the 2 shelf colonies $(p>0.05)$. Sample sizes are given inside or above bars

brates $(63 \% ; n=19)$ and sandlance $(72 \%, n=7)$ were mostly found in combination with other fish species.

\section{Corticosterone}

CORT levels of kittiwakes varied significantly among colonies $\left(F_{2,98}=8.741, \mathrm{p}<0.001\right)$. Birds nesting on both Pribilof colonies had significantly higher CORT levels than their counterparts nesting on Bogoslof (post hoc tests: $p<0.0007$; Fig. 4D). No significant differences in CORT levels were found between birds from St. Paul and St. George ( $p=0.99)$.

\section{Breeding and foraging performance}

Breeding success (chicks fledged per nest) of kittiwakes varied significantly among colonies $\left(F_{2,591}=\right.$ 159.3, p < 0.0001; Fig. 4B), with breeding success at Bogoslof 10 times higher than at the Pribilofs (post hoc test: $p<0.0001$ ). Ninety-two percent of nests with eggs failed during the incubation period at both Pribilof colonies, whereas only $23 \%$ of nests failed at Bogoslof. Similarly, fledgling success (chicks fledged per chicks hatched) differed among islands $\left(F_{2,119}=\right.$ 2.753, $\mathrm{p}=0.01$ ), with fledging success at Bogoslof significantly higher than at St. Paul (post hoc tests: $\mathrm{p}=$ 0.001; Fig. 4C), but not higher than at St. George ( $p>$ 0.05). No differences were found in either breeding or fledgling success between the Pribilof colonies (post hoc tests: $\mathrm{p}>0.05$ ).

\section{DISCUSSION}

Kittiwakes Rissa tridactyla nesting at the Pribilof colonies responded with 2 different foraging strategies to reduced availability of key forage fish in the continental shelf regions (Ianelli et al. 2009, Lauth 2010, Benoit-Bird et al. 2011). Individual birds from St. George conducted the longest trip distances recorded for kittiwakes (Suryan et al. 2000, Kotzerka et al. 2010), and the majority of birds concentrated foraging in oceanic habitats rather than in the nearby 
continental shelf regions. Birds from St. Paul foraged mainly in nearby shelf habitats and made shorter distance trips equivalent to birds at Bogoslof. Nonetheless, the food-energy content of St. Paul birds (declining population) was lower compared to the food-energy content of St. George (stable population) and Bogoslof (increasing population) birds. Although kittiwakes showed substantial flexibility in foraging behavior, individuals breeding on the Pribilof colonies still had higher nutritional stress and lower reproductive performance than birds breeding at Bogoslof.

\section{Bering Sea kittiwake foraging patterns}

Other studies have found that kittiwakes forage mostly during the daytime (Suryan et al. 2002, Kotzerka et al. 2010), and overnight foraging has been shown to occur more often in years of poor food availability (Hamer et al. 1993). Kittiwakes from the 3 Bering Sea colonies conducted shorter daytime and longer overnight trips, a pattern similar to dual foraging strategies reported in other seabirds (Chaurand \& Weimerskirch 1994, Saraux et al. 2011). In this study, birds only adjusted overnight trip distances, apparently in response to differences in prey availability among colonies. Overnight foraging may have allowed this surface-feeding species to access distant feeding grounds and rely on fish migrating from depth to the sea surface at night (juvenile pollock: Benoit-Bird et al. 2011; myctophids: Nishimura et al. 1999, Sinclair \& Stabeno 2002). On average, females from the 3 colonies made longer distance trips than males, results supporting other studies showing a female-biased role in chick-provisioning in the kittiwake (Jodice et al. 2006b and references therein).

\section{Differences in foraging and prey availability among colonies}

Previous studies have shown that kittiwakes' foraging effort, nutritional stress levels, and productivity are affected by differences in prey availability between colonies and years (Suryan et al. 2000, Gill \& Hatch 2002, Buck et al. 2007, Kitaysky et al. 2010). Concurrently, we found that birds from both shelf-located colonies (St. George and St. Paul) conducted longer overnight trips and had lower breeding success and higher levels of nutritional stress than birds breeding at the basin-located colony (Bogoslof). Independent ship-based surveys on the continental shelf during the summer 2009 (Ianelli et al. 2009, Lauth 2010, Benoit-Bird et al. 2011) indicate a low abundance and patchy distribution of key forage fish species (juvenile pollock: Ianelli et al. 2009, Benoit-Bird et al. 2011; capelin and sandlance: Lauth 2010). Interestingly, an estimated biomass of juvenile pollock near Bogoslof was also the lowest recorded since 1998 (Ianelli et al. 2009). Our results on bird diets support the at-sea surveys and indicate that invertebrates and fish offal were an alternative source of food for kittiwakes breeding on the Pribilof Islands. In contrast, Bogoslof kittiwakes fed mainly on mesopelagic myctophids and did not feed on fish offal, despite large volumes of offal being discarded locally by both the eastern Bering Sea and Aleutian Island ground fishery (Furness et al. 2007). Our results suggest that forage fish availability on the continental shelf was insufficient to maintain adequate provisioning rates of chicks and adult maintenance on the Pribilof Islands and that offal discards may not be sufficient to compensate for low availability of preferred prey.

Under conditions of low forage fish availability on the shelf, St. Paul birds increased overnight foraging distances over the shelf, apparently to access better feeding areas. Their core feeding areas coincided with larger patches of juvenile pollock found 60 to $170 \mathrm{~km}$ northwest of the island (Benoit-Bird et al. 2011). Interestingly, birds fed on age-1 pollock, which is larger and higher in energy content than age- 0 pollock (Whitman 2011), despite the occurrence of both age classes in the same patches (Benoit-Bird et al. 2011). St. George birds also increased overnight foraging ranges (up to $195 \mathrm{~km}$ ), but, in contrast to St. Paul birds, they accessed oceanic waters. This behavior combined with the high occurrence of lipid-rich myctophids in diets suggests that St. George kittiwakes relied on nocturnally available mesopelagic prey. Bogoslof kittiwakes also fed on the myctophids Stenobrachius leucopsaurus at night, but the proximity of Bogoslof to the Aleutian Islands also provided an additional source of myctophids (S. nannochir) in shallower waters during the daytime.

Despite flexibility in foraging behavior, with different strategies exhibited by the 2 shelf colonies in 2009, kittiwakes were unable to buffer apparent food shortages. Breeding success at St. Paul and St. George in 2009 ( $<0.05$ chicks fledged per nest) was below the historical (1975 to 2005) average for these colonies ( 0.24 to 0.30 chicks fledged per nest; Byrd et al. 2008a), as well as for other kittiwake colonies elsewhere (Suryan et al. 2000, Jodice et al. 2006a, Buck et al. 2007). Breeding success at Bogoslof in 2009 (0.57 chicks fledged per nest) was slightly below the long- 
term mean (0.68 chicks fledged per nest; Renner \& Williams 2005), but higher than at the Pribilofs and other colonies in the Pacific (Satterthwaite et al. 2012). Although fledgling success of kittiwakes at Bogoslof was higher than at St. Paul, foraging ranges were similar and both were longer overall than those reported at other localities (Ainley et al. 2003 and references therein, Kotzerka et al. 2010). Therefore, foraging conditions for kittiwakes at Bogoslof in 2009 might also have been suboptimal, but, in contrast to the Pribilof kittiwakes, birds breeding on Bogoslof were able to compensate by employing flexible foraging strategies and having access to multiple foraging habitats.

Density-dependent mechanisms have been proposed to explain differences in seabird foraging range and productivity (Hunt et al. 1986, Lewis et al. 2001, Ainley et al. 2003), but results obtained in this study do not support this hypothesis. As expected based on colony size, birds at the smaller colonies of St. Paul and Bogoslof conducted shorter overnight foraging trips than birds at the larger colony of St. George. However, contrary to predictions based on colony size, daytime foraging trip distances did not differ among the colonies. Furthermore, patterns of productivity and stress did not support the densitydependent hypothesis. Specifically, we observed a large difference in productivity and stress levels between the 2 similar-sized small colonies (St. Paul and Bogoslof) and little difference in those parameters between the 2 Pribilof colonies that have very different population sizes. According to the densitydependent mechanism hypothesis, depletion of the primary food (e.g. juvenile pollock and sandlance; Sinclair et al. 2008) should have had a stronger effect on the larger St. George colony; however, we found that here kittiwakes fed on higher quality prey than those at the smaller St. Paul colony.

Altogether these results suggest that proximity to alternative foraging habitats rather than densitydependent mechanisms might be important for explaining seabird reproductive and population processes. When the abundance of key forage fishes is reduced, kittiwakes at Bogoslof have much easier access to high-energy prey in nearby oceanic waters than the birds breeding on the Pribilof colonies.

\section{Relationships between foraging effort, physiological stress and reproductive performance}

Our results clearly show that the increased foraging effort of kittiwakes nesting at the shelf colonies affected their reproductive performance. These chan- ges also resulted in elevated CORT levels of the birds breeding at the shelf colonies; elevated CORT is a proximate mechanism of decreased reproductive performance in seabirds (Kitaysky et al. 2007, Buck et al. 2007, Kitaysky et al. 2010). Flying may be energetically costly (Norberg 1986), especially for birds like kittiwakes that use a flapping type of flight, but additional distance traveled may be energetically beneficial if individuals can access a greater amount of high-energy prey (e.g. myctophids and age-1 pollock; Whitman 2011). For example, although foraging effort by birds on St. George appeared to be greater than at St. Paul, because of the longer distance trips conducted at night, St. George kittiwakes consumed energy-rich prey. Thus, the additional flight costs associated with the long-distance trips conducted by St. George birds could be balanced by the high-energy prey taken by them in the basin. Nevertheless, despite the different foraging strategies exhibited by kittiwakes at the 2 islands in response to a food shortage, they incurred comparable levels of nutritional stress in 2009. Recent studies have shown that CORT levels are positively correlated with post-breeding mortality of adult kittiwakes (Kitaysky et al. 2010, Goutte et. al. 2010, Satterthwaite et al. 2012). Thus, the poor foraging conditions in 2009 likely affected the fitness of kittiwakes at the Pribilofs via decreased productivity and increased mortality of adults (Satterthwaite et al. 2012). However, the high-quality diets of St. George kittiwakes might have additional benefits for the survival of young kittiwakes. For example, the nutritional quality of prey during development has been shown to affect individual fledgling quality and might be important for the survival of juvenile kittiwakes (Kitaysky et al. 2006). Accordingly, post-fledging survival of St. George juvenile kittiwakes fed high-quality food might be enhanced compared to those fed poor-quality food on St. Paul, which might contribute to the contrasting population trends observed at the colonies during recent decades. Further examination of foraging behavior of individual birds in relation to their stress levels, prey quality, and survival would be important to determine whether food stress is a primary factor determining the population trajectories of Pribilof kittiwakes.

\section{Proximity to multiple marine habitats and population trends}

Contrary to what was proposed in earlier studies at the Pribilof Islands (Schneider \& Hunt 1984), birds at St. George colony did not focus their foraging on the 
nearby productive shelf break, but instead used the oceanic basin as an alternative source of lipid-rich forage fish. Similarly, Bogoslof birds used the Aleutian coast more often than the nearby Aleutian shelf break. It is possible that the shelf break zones used by kittiwakes were not as attractive due to annual changes in productivity (Mizobata et al. 2008, Brown et al. 2011) and/or increased competition by other seabirds and marine mammals at this well-known feature (Schneider \& Hunt 1984, Springer et al. 1996a). The consistent SW direction of St. George foraging tracks to the basin, coupled with the presence of core feeding areas and a high occurrence of myctophids in the diet of St. George and Bogoslof kittiwakes, suggests there were predictable prey aggregations at the mesoscale level in the oceanic basin. Eddies produced by currents associated with the shelf break play an important role in consolidating planktonic organisms at the sea surface and creating feeding opportunities for species at higher trophic levels such as larval pollock (Schumacher \& Stabeno 1994), myctophids (Sinclair \& Stabeno 2002), and northern fur seals Callorhinus ursinus (Sterling 2009). Thus, we suggest that there may be indirect benefits of the closer proximity of St. George and Bogoslof colonies to the shelf breaks, with eddies providing predictable areas for kittiwakes to forage in the basin. Prey availability, however, is not always low on the shelf, and the productivity of birds from St. Paul has been higher than that of birds from St. George in some years (Byrd et al. 2008a). Thus, foraging and breeding patterns may differ in warmer years, when feeding conditions are apparently better for piscivore seabirds nesting at the Pribilof Islands (Benowitz-Fredericks et al. 2008, Satterthwaite et al. 2012). In addition, the energy density of age-1 pollock can vary among years and habitat zones and is sometimes comparable to that of myctophids (Whitman 2011). Hot spots of a key forage species, juvenile pollock, have been found northwest of St. Paul, near the $100 \mathrm{~m}$ isobaths, in multiple years (Sigler et al. 2012), and it is likely that St. Paul birds would do better when those patches are closer and abundant. However, if these patches move farther north or descend deeper into the water column on the continental shelf, birds at the St. Paul colony are likely to be less able to cope. Conversely, birds at the Bogoslof colony appear most resilient to changes in food availability on the shelf, likely because they are closer to 3 nearby habitats (basin, shelf break, and Aleutian Islands) with high-quality prey. Long-term declines in the availability of forage fishes on the Bering Sea shelf may, therefore, have had a greater impact on kittiwake populations at St. Paul due to limited alternative foraging opportunities. The declines appear to have had a lesser, although still significant, impact on birds nesting at St. George, with the least effect on kittiwakes from Bogoslof.

In conclusion, our integrative study highlights the importance of accessibility to alternative foraging habitats and associated prey for breeding seabirds, implying a differential vulnerability of seabird colonies to a changing environment according to their location. Our results provide new insights into our current understanding of the use of marine habitats by breeding seabirds, elucidate causes for the contrasting population trends observed at the study colonies, and have implications for both research priorities and management plans for marine habitats.

Acknowledgements. This collaborative study was part of the Bering Sea Integrated Ecosystem program funded by The North Pacific Research Board. We are grateful for the enthusiastic assistance and excellent work of crew members: Brie Drummond, John Warzybok, Ine Dorreteijn, Dean Kildaw, Rob Massangale, Ram Papish, Tom Harten, Chris Barger, Brian Battaile, Dan Cushing, Alexis Will, Sarah Youngren, and Rob Marshall. In addition, Alexis Will did a great job with data entry and preliminary analysis of behavioral data. We thank Zhenya Kitaiskaia for conducting hormonal assays, and Kathy Turco for expert diet analyses. We thank Karin Holser (St. George Island Institute), Sally and Chris Merculief (Traditional Tribal Council of St. George Island), Phil Zavadil and Debbie Lestenkof (Aleut Community of St. Paul Island), and Priscilla Wohl and Arina Purcella (Northern Forum) for logistical and financial assistance. We also are grateful to Jeff Williams, John Reed, and the crews of the MV 'Tiglax' and 'Miss Alyssa' for crucial Bogoslof logistics. Thanks to Karen Brenneman and Michelle St. Peters (USFWS-Anchorage) for invaluable expeditor assistance. Bruce Robson, Steve Insley, Scott Shaffer, and Carlos Zavalaga provided technical and academic assistance in the early stages of the telemetry project. This study was funded by NPRB BSIERP Projects B63 and B77 to David Irons and Dan Roby, Project B65 to Heather Renner, and Project B77 to Alexander Kitaysky. This is Contribution No. 362 of the North Pacific Research Board and No. 68 of the BESTBSIERP Bering Sea Project.

\section{LITERATURE CITED}

Ainley DA, Ford RG, Brown ED, Suryan RM, Irons DB (2003) Prey resources, competition, and geographic structure of kittiwake colonies in Prince William Sound. Ecology 84: 709-723

Anthony JA, Roby DD, Turco KR (2000) Lipid content and energy density of forage fishes from the northern Gulf of Alaska. J Exp Mar Biol Ecol 248:53-78

Aydin K, Gaichas S, Ortiz I, Kinzey D, Friday N (2007) A comparison of the Bering Sea, Gulf of Alaska, and Aleutian Islands large marine ecosystems through food web modeling. US Dep Commer, NOAA Tech Memo, NMFSAFSC-178, p 109-110 
Batchelor AL, Ross GJB (1984) The diet and implications of dietary change of Cape gannets on Bird Island, Nelson Mandela Bay. Ostrich 55:45-63

Benoit-Bird KJ, Kuletz K, Heppell S, Jones N, Hoover B (2011) Active acoustic examination of the diving behavior of murres foraging on patch prey. Mar Ecol Prog Ser 443:217-235

> Benowitz-Fredericks MZ, Shultz MT, Kitaysky AS (2008) Stress hormones suggest opposite trends of food availability for planktivorous and piscivorous seabirds in 2 years. Deep-Sea Res II 55:1868-1876

> Boersma PD, Rebstock GA (2009) Foraging distance affects reproductive success in Magellanic penguins. Mar Ecol Prog Ser 375:263-275

> Brown ZW, van Dijken GL, Arrigo KR (2011) A reassessment of primary production and environmental change in the Bering Sea. J Geophys Res 116:C08014, doi:10.1029/ 2010JC006766

> Bryant R, Jones IL, Hipfner JM (1999) Responses to changes in prey availability by common murres and thick-billed murres at the Gannet Islands, Labrador. Can J Zool 77 : 1278-1287

> Buck CL, O'Reilly KM, Kildaw SD (2007) Interannual variability of black-legged kittiwake productivity is reflected in baseline plasma corticosterone. Gen Comp Endocrinol 150:430-436

Byrd GV, Sydeman WJ, Renner HM, Minobe S (2008a) Responses of piscivorous seabirds at the Pribilof Islands to ocean climate. Deep-Sea Res II 55:1856-1867

> Byrd GV, Schmutz JA, Renner HM (2008b) Contrasting population trends of piscivorous seabirds in the Pribilof Islands: a 30 year perspective. Deep-Sea Res II 55: 1846-1855

Chaurand T, Weimerskirch H (1994) Regular alternation of short and long foraging trips in the blue petrel Halobaena caerulea: a previously undescribed strategy of food provisioning in a pelagic seabird. J Anim Ecol 63: 275-282

Croxall JP, Wood AG (2002) The importance of the Patagonian Shelf for top predator species breeding at South Georgia. Aquat Conserv 12:101-118

Cury PM, Boyd IL, Bonhommeau S, Anker-Nilssen T and others (2011) Global seabird response to forage fish depletion-One-third for the birds. Science 334: 1703-1706

> Dorresteijn I, Kitaysky AS, Barger C, Benowitz-Fredericks ZM, Byrd GV, Schultz M, Young R (2012) Climate variability affects food availability to planktivorous least auklets, Aethia pusilla, through physical processes in the southeastern Bering Sea. Mar Ecol Prog Ser 454:207-220

- Einoder LD, Page, B, Goldsworthy SD, DeLittle SC, Bradshaw CJA (2011) Exploitation of distant Antarctic waters and close neritic waters by short-tailed shearwaters breeding in South Australia. Austral Ecol 36:461-475

> Fridolfsson AK, Ellegren H (1999) A simple and universal method for molecular sexing of non-ratite birds. J Avian Biol 30:116-121

> Furness RW, Edwards AE, Oro D (2007) Influence of management practices and of scavenging seabirds on availability of fisheries discards to benthic scavengers. Mar Ecol Prog Ser 350:235-244

Gill VA, Hatch SA (2002) Components of productivity in black-legged kittiwakes Rissa tridactyla: response to supplemental feeding. J Avian Biol 33:113-126

Golet GH, Kuletz KJ, Roby DD, Irons DB (2000) Adult prey choice affects chick growth and reproductive success in pigeon guillemots. Auk 117:82-91

Goutte A, Angelier F, Welcker J, Moec B and others (2010) Long-term survival effect of corticosterone manipulation in black-legged kittiwakes. Gen Comp Endocrinol 167: 246-251

> Grebmeier JM, Overland JE, Moore SE, Farley EV and others (2006) A major ecosystem shift in the northern Bering Sea. Science 311:1461-1464

> Hamer K, Monaghan CP, Uttley JD, Walton P, Burns MD (1993) The influence of food supply on the breeding ecology of kittiwakes Rissa tridactyla in Shetland. Ibis 135: 255-263

> Harding AM, Welcker J, Seen H, Hamer KC and others (2011) Adverse foraging conditions may impact body mass and adult survival of a high Arctic seabird. Oecologia 167:49-59

Hickey JJ, Craighead FL (1977) A census of seabirds on the Pribilof Islands. In: Environmental assessment of the Alaskan Continental Shelf. Final Reports of Investigators, Vol. 2. BLM/NOAA/OMPA, Boulder, CO, p 96-195

Hunt GL Jr, Eppley Z, Schneider D (1986) Reproductive performance of seabirds: the importance of population and colony size. Auk 103:306-317

> Hunt GL Jr, Stabeno PJ, Strom S, Napp JM (2008) Patterns of spatial and temporal variation in the marine ecosystem of the southeastern Bering Sea, with special reference to the Pribilof Domain. Deep-Sea Res II 55:1919-1944

Hunt GL Jr, Coyle KO, Eisner L, Farley EV and others (2011) Climate impacts on eastern Bering Sea food webs: a synthesis of new data and an assessment of the oscillating control hypothesis. ICES J Mar Sci 68:1230-1243

- Huyer A (1983) Coastal upwelling in the California current system. Prog Oceanogr 12:259-284

Ianelli JN, Barbeaux S, Honkalehto T, Kotwicki S, Aydin K, Williamson N (2009) Assessment of walleye pollock in the eastern Bering Sea and Bogoslof Region, Chapters 1 \& 1B. In: Stock assessment and fishery evaluation report for the groundfish resources of the Bering Sea/Aleutian Islands regions. North Pacific Fishery Management Council, Anchorage, AK, p 47-234

Irons DB (1998) Foraging area fidelity of individual seabirds in relation to tidal cycles and flock feeding. Ecology 79 : $647-655$

> Irons DB, Anker-Nilssen T, Gaston AJ, Byrd GV and others (2008) Fluctuations in circumpolar seabird populations linked to climate oscillations. Glob Change Biol 14: 1455-1463

Iverson SJ, Springer AM, Kitaysky AS (2007) Seabirds as indicators of food web structure and ecosystem variability: qualitative and quantitative diet analyses using fatty acids. Mar Ecol Prog Ser 352:235-244

> Jackson JBC, Kirby MX, Berger WH, Bjorndal KA and others (2001) Historical overfishing and the recent collapse of coastal ecosystems. Science 293:629-637

> Jodice PGR, Roby DD, Turco KR, Suryan RM and others (2006a) Assessing the nutritional stress hypothesis: the relative influence of diet quantity and quality on seabird productivity. Mar Ecol Prog Ser 325:267-279

Jodice PGR, Roby DD, Suryan RM, Irons DB and others (2006b) Increased energy expenditure by a seabird in response to higher food abundance. Mar Ecol Prog Ser 306:283-293

Kitaysky AS, Wingfield JC, Piatt JF (1999) Food availability, body condition and physiological stress response in 
breeding black-legged kittiwakes. Funct Ecol 13:577-584

Kitaysky AS, Kitaiskaia EV, Piatt JF, Wingfield JC (2006) A mechanistic link between chick diet and decline in seabirds? Proc Biol Sci 273:445-450

Kitaysky AS, Piatt JF, Wingfield JC (2007) Stress hormones link food availability and population processes in seabirds. Mar Ecol Prog Ser 352:245-258

Kitaysky AS, Piatt JF, Hatch SA, Kitaiskaia EV, BenowitzFredericks M, Shultz MT, Wingfield JC (2010) Food availability and population processes: severity of nutritional stress. Funct Ecol 24:625-637

Kotzerka J, Hatch SA, Garthe SE (2010) GPS tracking devices reveal foraging strategies of black-legged kittiwakes. J Ornithol 151:459-467

Ladd C, Hunt GL Jr, Mordy CW, Salo S, Stabeno P (2005) Marine environment of the eastern and central Aleutian Islands. Fish Oceanogr 14:22-38

Laidre KL, Heide-Jørgensen MP, Nyeland J, Mosbech A, Boertmann D (2008) Latitudinal gradients in sea ice and primary production determine Arctic seabird colony size in Greenland. Proc Biol Sci 275:2695-2702

Lauth RR (2010) Results of the 2009 eastern Bering Sea continental shelf bottom trawl survey of groundfish and invertebrate resources. US Dep Commer, NOAA Tech Memo NMFS-AFSC-204, p 130-188

> Lewis S, Sherratt TN, Hamer KC, Wanless S (2001) Evidence of intra-specific competition for food in a pelagic seabird. Nature 412:816-819

- Mattern T, Houston DM, Lalas C, Setiawan AN, Davis LS (2009) Diet composition, continuity in prey availability and marine habitat - keystones to population stability in the snares penguin (Eudyptes robustus). Emu 109:204-213

> MacArthur RH, Pianka ER (1966) Optimal use of a patchy environment. Am Nat 100:603-609

$>$ McConnell BJ, Chambers C, Fedak MA (1992) Foraging ecology of southern elephant seals in relation to the bathymetry and productivity of the Southern Ocean. Antarct Sci 4:393-398

Mizobata K, Saitoh S, Wang J (2008) Interannual variability of summer biochemical enhancement in relation to mesoscale eddies at the shelf break in the vicinity of the Pribilof Islands, Bering Sea. Deep-Sea Res II 55:1717-1728

> Mullers RHE, Navarro RA, Crawford RJM, Underhill LG (2009) The importance of lipid-rich fish prey for Cape gannet chick growth: Are fishery discards an alternative? ICES J Mar Sci 66:2244-2252

Naef-Daenzer B (2000) Patch time allocation and patch sampling by foraging great and blue titis. Anim Behav 59: 989-999

Nishimura A, Nagasawa K, Asamuma T, Aoki H, Kubota T (1999) Age, growth, and feeding habits of lanternfish, Stenobrachius leucopsarus (Myctophidae), collected from the near-surface layer in the Bering Sea. Fisheries Sci 65:11-15

Norberg UM (1986) Flying, gliding, and soaring. In: Hildebrand M, Bramble DM, Liem KF, Wake DB (eds) Functional vertebrate morphology. Belknap Press of Harvard University, Cambridge, MA

Orians GH, Pearson NE (1979) On the theory of central place foraging. In: Horn DJ, Mitchell RD, Stairs GR (eds) Analysis of ecological systems. Ohio State University Press, Columbus, OH, p 155-177

$>$ Oro D, Furness RW (2002) Influences of food availability and predation on survival of kittiwakes. Ecology 83: 2516-2528
Piatt JF, Harding AMA, Shultz M, Speckman SG, Van Pelt II, Drew GS, Kettle AB (2007) Seabirds as indicators of marine food supplies: Cairns revisited. Mar Ecol Prog Ser 352:221-234

Rainho A, Palmeirim JM (2011) The importance of distance to resources in the spatial modelling of bat foraging habitat. PLoS ONE 6:e19227

Renner HM, Williams JC (2005) Marine bird surveys at Bogoslof Island, Alaska in 2005. Report AMNWR 05/18, US Fish and Wildlife Service, Washington, DC

Renner HM, Meuter F, Warzybok JA, Drummond BA, Sinclair EH (2012) Patterns of change in diets of seabirds in the Pribilof Islands: relationships with environmental conditions and chick survival. Deep-Sea Res II 65-70: 273-291

Romano M, Piatt JF, Roby DD (2006) Testing the junk-food hypothesis on marine birds: effects of prey type on growth and development. Waterbirds 29:407-414

Saraux C, Robinson-Laverick SM, Le Maho Y, Ropert-Coudert Y, Charadia A (2011) Plasticity in foraging strategies of inshore birds: how little penguins maintain body reserves while feeding offspring. Ecology 92:1909-1916

Satterthwaite WH, Kitaysky AS, Mangel M (2012) Linking climate variability, productivity and stress to demography in a long-lived seabird. Mar Ecol Prog Ser 454:221-235

Schneider D, Hunt GL Jr (1984) A comparison of seabird diets and foraging distribution around the Pribilof Islands, Alaska. In: Nettleship D, Sanger G, Springer P (eds) Marine birds: their feeding ecology and commercial fisheries relationships. Special publication, Canadian Wildlife Service, Gatineau, p 86-95

$>$ Schumacher JD, Stabeno PJ (1994) Ubiquitous eddies of the eastern Bering Sea and their coincidence with concentrations of larval pollock. Fish Oceanogr 3:182-190

Sigler MF, Kuletz KJ, Ressler PH, Friday NA, Wilson CD, Zerbini AN (2012) Marine predators and persistent prey in the southeast Bering Sea. Deep-Sea Res II 65-70: 292-303

Sinclair EH, Stabeno PJ (2002) Mesopelagic nekton and associated physics of the southeastern Bering Sea. DeepSea Res II 49:6127-6145

Sinclair EH, Vlietstra LS, Johnson DS, Zeppelin TK and others (2008) Patterns in prey use among fur seals and seabirds in the Pribilof Islands. Deep-Sea Res II 55: 1897-1918

- Springer AM, McRoy CP, Flint MV (1996a) The Bering Sea green belt: shelf-edge processes and ecosystem production. Fish Oceanogr 5:205-223

Springer AM, Piatt JF, Vliet GV (1996b) Seabirds as proxies of marine habitats and food webs in the western Aleutian Arc. Fish Oceanogr 5:45-55

Stabeno PJ, Kachel NB, Moore SB, Napp JM, Sigler M, Yamaguchi A, Zerbini AN (2012) Comparison of warm and cold years on the southeastern Bering Sea shelf and some implications for the ecosystem. Deep-Sea Res II 65-70:31-45

Stearns SC (1992) The evolution of life histories. Oxford University Press, Oxford

Sterling JT (2009) Northern fur seal foraging behaviors, food webs, and interactions with oceanographic features in the eastern Bering Sea. PhD dissertation, University of Washington, Seattle, WA

Suryan RM, Irons DB, Benson J (2000) Prey switching and variable foraging strategies of black-legged kittiwakes and the effect on reproductive success. Condor 102: 
374-384

Suryan RM, Irons DB, Kaufman M, Jodice PGR, Roby DD, Benson J, Brown ED (2002) Short-term fluctuations in forage fish availability and the effect on prey selection and brood-rearing in the black-legged kittiwake. Mar Ecol Prog Ser 236:273-287

Tremblay Y, Cherel Y, Oremus M, Tveraa T, Chastel O (2003) Unconventional ventral attachment of time-depth recorders as a new method for investigating time budget and diving behaviour of seabirds. J Exp Biol 206: 1929-1940

USFWS (US Fish and Wildlife Service) (1997) Standard operating procedures for population inventories: ledge nesting seabirds. US Fish and Wildl Ser Rep, Homer, AK

> Van Pelt TI, Piatt JF, Lance BK, Roby DD (1997) Proximate composition and energy density of some North Pacific forage fishes. Comp Biochem Physiol A 118:1393-1398

Weimerskirch H (2007) Are seabirds foraging for unpredictable resources? Deep-Sea Res II 54:211-223

Whitman L (2011) Variation in the energy density of forage fishes and invertebrates from the southeastern Bering Sea. PhD dissertation, Oregon State University, Corvallis, OR

Williams GC (1966) Natural selection, the costs of reproduction and a refinement of Lack's principle. Am Nat 100: 687-690

Wilson RP (1984) An improved stomach pump for penguins and other seabirds. J Field Ornithol 55:109-112

- Zainuddin M, Kiyofuji H, Saitoh K, Saitoh SI (2006) Using multi-sensor remote sensing and catch data to detect ocean hot spots for albacore (Thunnus alalunga) in the northwestern North Pacific. Deep-Sea Res II 53:419-431

Appendix 1. GLM analysis of maximum trip distance using colony, body condition, and corticosterone (CORT) levels as explanatory variables

We conducted a GLM analysis of trip distance using colony, body condition, and CORT as explanatory variables to examine whether foraging effort was affected by adult condition and CORT at deployment. Body condition index was estimated using principal component analysis of body measurements (tarsus, wing, and head-bill) and mass (see below for details). The first principal component (PC1) explained $45.6 \%$ of the variation in body measurements (wing, tarsus, and head-bill). We used a linear model of body mass predicted by PC1 to obtain fitted values of PC1 on body mass and residuals of PC1. Standardized body condition was calculated as the residuals divided by the fitted values.

We did not find a significant effect of any of the independent variables (colony, body condition, CORT) on trip distance ( $p>0.05$; see Table A1). However, small sample sizes may have precluded detection of CORT and body condition effects: many tags stopped collecting data before birds were recaptured, and only few birds (e.g. St. George $=4$; Bogoslof $=5$; St. Paul $=10$ ) provided complete information on trip distance.

Table A1. Rissa tridactyla. Effects of colony, body condition and corticosterone (CORT) levels on trip distance. Significance at $\mathrm{p}<0.05$

\begin{tabular}{|llll|}
\hline Term & df & $F$ & $\mathrm{p}$ \\
\hline CORT & 1 & 2.54 & 0.16 \\
Colony & 2 & 0.649 & 0.55 \\
Body Condition & 1 & 1.19 & 0.31 \\
CORT $\times$ Colony & 2 & 0.0536 & 0.95 \\
CORT $\times$ Body condition & 1 & 1.04 & 0.34 \\
Colony $\times$ Body condition & 2 & 0.686 & 0.53 \\
CORT $\times$ Colony $\times$ body condition & 2 & 0.297 & 0.75 \\
\hline
\end{tabular}

Submitted: December 29, 2011; Accepted: September 5, 2012 Proofs received from author(s): November 26, 2012
Editorial responsibility: Jacob González-Solís, Barcelona, Spain 